\title{
Analisis Tentang Pengaruh Pelatihan Dan Keterampilan Terhadap Keberhasilan Usaha Mitra Binaan PT Karya Masyarakat Mandiri Dompet Dhuafa Republika
}

\author{
Kosasih \\ Universitas Sangga Buana \\ Email: kosasih@gmail.com
}

\begin{abstract}
The purpose of this research was to obtain empirical evidence through data analysis on the influence of training and skills on the businesses success of PT Karya Masyarakat Mandiri Dompet Dhuafa Republika fostered partner in the Jakarta Region. The research method used in this research is descriptive and verification method with a quantitative approach and uses multiple linear regression analysis. Data collection techniques used were observation on 6 fostered partners in the Jakarta Region, 50 respondents through questionnaires equipped with interviews. The results showed that both partially and simultaneously between training and skills had a positive effect on business success. This means that the better the training and skills of the fostered partners, will be successful the business. As well as the most dominant influenced to business success is skill, meaning that with good skills, business success automatically increases.
\end{abstract}

Keywords: Training, Skills, and Business Success

Abstrak. Tujuan penelitian ini adalah untuk memperoleh bukti empirik melalui analisis data tentang pengaruh pelatihan dan keterampilan terhadap keberhasilan usaha mitra binaan PT Karya Masyarakat Mandiri Dompet Dhuafa Republika di Wilayah Jakarta. Metode penelitian yang digunakan dalam penelitian ini adalah metode deskriptif dan verifikatif dengan pendekatan kuantitatif dan menggunakan analisis regresi linier berganda. Teknik pengumpulan data yang digunakan adalah dengan cara observasi pada 6 mitra binaan PT Karya Masyarakat Mandiri Dompet Dhuafa Republika di Wilayah Jakarta dengan jumlah responden 50 orang melalui kuesioner dilengkapi dengan wawancara. Hasil penelitian menunjukkan bahwa baik secara parsial maupun secara simultan antara pelatihan dan keterampilan berpengaruh positif terhadap keberhasilan usaha. Hal ini berarti semakin baik pelatihan dan keterampilan mitra binaan, akan semakin meningkat keberhasilan usahanya. Serta yang paling besar dominan mempengaruhi keberhasilan usaha adalah keterampilan, artinya dengan keterampilan yang baik, secara otomatis keberhasilan usaha juga meningkat.

Kata Kunci : Pelatihan, Keterampilan, dan Keberhasilan Usaha

\section{A. PENDAHULUAN}

Pertumbuhan ekonomi dan teknologi telekomunikasi saat ini sangat pesat dan dampaknya diharapkan dapat dirasakan sejalan dengan meningkatnya tingkat kesejahteraan masyarakat. Namun kenyataannya tingkat pemerataanya masih memprihatinkan karena masih banyak masyarakat Indonesia yang tingkat pendapatannya masih rendah dan tingkat pendidikan yang masih rendah pula, sehingga terjadi kesenjangan kesejahteraannya. Hal ini masih belum sesuai dengan cita-cita dan harapan UUD 1945 Pasal 27 ayat 2 yang 
berbunyi "Tiap-tiap warga negara berhak atas pekerjaan dan penghidupan yang layak bagi kemanusiaan". Peran dari seluruh pemangku kepentingan (stake holders) sangat diharapkan dapat memberikan solusi dalam mengatasi kesenjangan peningkatan kesejahteraan masyarakat tersebut.

Salah satu stake holder Usaha Mikro, Kecil, dan Menengah (UMKM) yang langsung terjun ke masyarakat adalah PT Karya Masyarakat Mandiri Dompet Dhuafa Republika yang merupakan sebuah lembaga nirlaba yang bergerak dalam bidang pemberdayaan masyarakat di pedesaan, perkotaan, dan komunitas pekerja migran. Proses pemberdayaan bertitik tolak memandirikan masyarakat untuk peningkatan taraf hidupnya dalam mendapatkan penghasilan yang layak, mengoptimalkan dengan sebaik mungkin sumber daya alam dan sumber daya manusia. Pendampingan merupakan salah satu upaya dalam menjalankan kesadaran komunitas untuk berubah dengan sumber daya yang milikinya, dengan visinya "Terdepan sebagai community enterprise di Indonesia melalui inovasi pemberdayaan masyarakat secara berkelanjutan".

PT Karya Masyarakat Mandiri Dompet Dhuafa Republika sejak tahun 2004 hingga sekarang telah melakukan pemberdayaan masyarakat guna meningkatkan taraf kehidupan masyarakat yang layak dibeberapa wilayah Indonesia. Program yang diberikan kepada masyarakat diantaranya adalah program usaha mikro dan ketahanan pangan seperti : petani, peternak, buruh, pengrajin, pelaku usaha (pedagang asongan, warung), kesehatan, tata boga, pendidikan dan lainnya yang didukung dengan perorganisasian dan pembukuan sederhana sampai pada pembentukan koperasi. Program tersebut dijalankan dengan pendampingan yang bertugas memfasilitasi komunitas mitra binaan dengan rangkaian kegiatan program pemberdayaan sampai benarbenar membawa manfaat bagi mereka dalam peningkatan kegiatan dan keberhasilan usahanya.

Sejalan dengan hal tersebut Suryana (2011:66) mengungkapkan bahwa "untuk menjadi wirausaha yang sukses harus memiliki ide atau visi bisnis yang jelas, ada kemauan, dan keberanian untuk menghadapi risiko baik waktu maupun uang". Sebagai wirausaha akan terkait dengan bagaimana keberhasilan usaha yang telah diperoleh atau dicapai. Keberhasilan usaha bisa dilihat dari keberhasilan organisasi/perusahaan dapat mencapai tujuan yang telah ditetapkan sebelumnya, seperti meningkatnya pendapatan, bertambahnya produktivitas usaha dan mempunyai citra baik di masyarakat.

Untuk pencapaian keberhasilan suatu program, banyak faktor yang dilakukan dalam pendampingan komunitas mitra binaan. Aktivitas yang dijalankan oleh PT Karya Masyarakat Mandiri merupakan program pendampingan komunitas mitra binaan yang telah lulus dalam tahapan seleksi yang telah dilakukan, yaitu pengecekan studi kelayakan dilapangan dan tes wawancara.

Pelaksanaan program yang telah dilakukan PT Karya Masyarakat Mandiri dengan masyarakat binaan dijalankan dari tahun 2004 hingga sekarang. Mitra binaan tersebar di 13 Provinsi, 36 Kabupaten/Kota, 81 Kecamatan, 123 Desa juga kelembagaan lokal yang terbentuk sebanyak 27 koperasi komunitas pendampingan dengan mendapatkan hasil $12.716 \mathrm{KK}$ atau 34.748 jiwa. Dalam pelaksanaan program tersebut tidak selalu berjalan sesuai dengan harapan yang berakibat komunitas mitra binaan tidak lagi 
diberikan permodalan atau diberhentikan dari program tersebut, karena kinerja kelompok pedagang mitra binaan sampai saat ini masih jauh untuk mencapai sesuai dengan yang diharapkan oleh pemberi pinjaman (pemodal). Diharapkan dengan dilakukannya pelatihan dan keterampilan dapat meningkatkan keberhasilan usaha para mitra binaan yang pada akhirnya dapat meningkatkan taraf hidup atau kesejahteraan masyarakat Indonesia.

Berdasarkan pengamatan penulis bahwa ketidakberhasilan usaha pedagang mitra binaan tersebut disebabkan oleh pelatihan yang dilakukan oleh PT Karya Masyarakat Mandiri Dompet Dhuafa Republika masih belum dapat diserap atau diterima dengan baik dan keterampilan (skill) para pedagang mitra binaan dalam melakukan usaha berjualan makanan (bakso, mie ayam, mie ayam bakso, dan bakso malang) masih rendah. Untuk menjaga dan membina agar usaha mitra binaan dapat bertahan dan berjalan berkelanjutan (sustainable) dengan baik, maka penulis melakukan penelitan tentang pengaruh pelatihan dan keterampilan terhadap keberhasilan usaha mitra binaan PT Karya Masyarakat Mandiri Dompet Dhuafa Republika.

\section{B. TUJUAN PENELITIAN}

Tujuan yang ingin dicapai dalam penelitian ini adalah :

1. Ingin mengetahui bagaimana pelaksanaan pelatihan Mitra Binaan UMKM PT Karya Masyarakat Mandiri Dompet Dhuafa Republika.

2. Ingin mengetahui bagaimana keterampilan Mitra Binaan UMKM PT Karya Masyarakat Mandiri Dompet Dhuafa Republika.

3. Ingin memperoleh bukti empiris tentang pengaruh pelatihan terhadap keberhasilan usaha Mitra Binaan UMKM PT Karya Masyarakat Mandiri Dompet Dhuafa Republika.

4. Ingin memperoleh bukti empiris tentang pengaruh keterampilan (skill) terhadap keberhasilan usaha Mitra Binaan UMKM PT Karya Masyarakat Mandiri Dompet Dhuafa Republika.

5. Ingin memperoleh bukti empiris tentang pengaruh pelatihan dan keterampilan (skill) secara simultan terhadap keberhasilan usaha Mitra Binaan UMKM PT Karya Masyarakat Mandiri Dompet Dhuafa Republika.

\section{Kegunaan Penelitian}

Hasil penelitian diharapkan dapat berguna untuk :

1. Kegunaan dalam akademis adalah untuk menambah wawasan dan keilmuan peneliti dalam mengembangkan dan menciptakan model sistem pelatihan dan keterampilan serta pembinaannya untuk keberhasilan usaha mitra binaan UMKM.

2. Kegunaan secara praktis adalah sebagai bahan masukan bagi institusi terkait dalam rangka pembinaan dan pengambilan keputusan dalam membantu keberhasilan pengembangan usaha para pengusaha mitra binaan UMKM.

\section{KAJIAN TEORI}

Penelitian ini terkait dengan teori terapan (applied theory) tentang pelatihan, keterampilan (skill), dan keberhasilan usaha.

\section{Pelatihan (Training)}

Pelatihan merupakan proses pendidikan jangka pendek dan terbatas dengan menggunakan prosedur yang sistematis untuk memperoleh keahlian dan pengetahuan sebagai hasil dari pembelajaran, sehingga dalam hal ini 
mitra binaan dalam berjualan mendapatkan teknik pengerjaan dan keahlian untuk mencapai keahlian tertentu dalam pekerjaaanya.

Menurut Kaswan (2013:2) pelatihan adalah proses meningkatkan pengetahuan dan keterampilan para karyawan. Kemudian, dimensi pelatihan menurut Rae dalam Sofyandi (2013:119) dimensi program pelatihan yang efektif yang diberikan perusahaan kepada karyawannya dapat diukur melalui : 1). Isi pelatihan. 2). Metode pelatihan 3). Sikap dan keterampilan instruktur. 4). Lama waktu pelatihan. 5). Fasilitas pelatihan.

Selanjunya Jiwo Wungu dan Hartanto Brotoharsojo (2003 :134), pelatihan pegawai atau training adalah upaya sistematik perusahaan untuk meningkatkan segenap pengetahuan (knowledge), keterampilan (skill), dan sikap-sikap kerja (attitudes) para pegawai melalui proses belajar agar optimal dalam menjalankan fungsi dan tugas-tugas jabatannya.

Gomes (2003:197) pelatihan adalah setiap usaha untuk memperbaiki kinerja pekerja pada suatu pekerjaan tertentu yang sedang menjadi tanggungjawabnya atau suatu pekerjaan yang ada kaitannya dengan pekerjaannya. Supaya efektif, pelatihan biasanya mencakup pengalaman belajar (learning experience), aktivitas-aktivitas yang terencana (be a planned organizational activity), didesain sebagai jawaban atas kebutuhankebutuhan yang berhasil diideintifikasikan. Secara ideal, pelatihan harus diwujudkan tujuantujuan organisasi, yang pada waktu yang bersamaan juga mewujudkan tujuantujuan dari para pekerja secara perseorangan. Kemudian Malayu (2012:69) menyatakan bahwa pelatihan/pengembangan adalah suatu usaha untuk meningkatkan kemampuan teknis, teoritis, konseptual, dan moral karyawan sesuai dengan kebutuhan pekerjaan/jabatan melalui pendidikan dan latihan.

Dapat disimpulkan bahwa pelatihan adalah rangkaian kegiatan terencana dari sebuah rencana program kerja tertentu untuk meningkatkan kinerja karyawan yang mengarah pada hasil-hasil bisnis yang dipandang sebagai pemecahan masalah dalam peningkatan kinerja yang meliputi : pengetahuan, keterampilan kerja, dan sikap kerja untuk memperbaiki dan memahami tanggungjawab, fungsi, dan tugasnya dalam menghadapi pekerjaan.

\section{Keterampilan (Skill)}

Keterampilan merupakan

kemampuan atau kapasitas seorang individu untuk melakukan beragam tugas dalam suatu pekerjaan. Keterampilan menurut Robbins (2000:494) adalah kemampuan untuk mengoperasikan suatu pekerjaan secara mudah dan cermat yang membutuhkan kemampuan dasar (basic ability), terdiri dari 4 dimensi yaitu : 1) Basic literacy skill. 2) Technical skill. 3) Interpersonal skill. 4) Problem solving.

Nadler (1986:112), menyatakan bahwa keterampilan merupakan kegiatan yang memerlukan praktek atau dapat diartikan sebagai implikasi dari aktivitas. Sjamsudin dan Maryani (2008:6) bahwa keterampilan sosial adalah suatu kemampuan secara cakap yang tampak dalam tindakan, mampu mencari, memilah, dan mengolah informasi, mampu mempelajari hal-hal baru yang dapat memecahkan masalah sehari-hari, memahami, menghargai, dan mampu bekerjasama dengan orang lain yang majemuk, mampu mentranformasikan kemampuan akademik, dan beradaptasi dengan perkembangan masyarakat. 
Kemudian Gordon (1994:50) keterampilan merupakan kemampuan dalam mengoperasikan pekerjaan secara mudah dan cermat (pengertian ini cenderung pada aktivitas psikomotor). Dimensi menurut Gordon sebagai berikut : 1) Basic Literacy Skill. 2) Technical Skill. 3) Interpersonal Skill. 4) Problem Solving. Selanjutnya Chang dan Rieple (2013:227), mengemukakan ada 4 dimensi keterampilan wirausaha yaitu : 1) Technical Skills. 2) Management Skills. 3) Entrepreneur Skills. 4) Personal Maturity Skills.

Dengan demikian dapat disimpulkan bahwa keterampilan adalah kemampuan untuk melakukan suatu pekerjaan secara mudah dan cermat yang menggunakan kemampuan dasar dan dapat mengantisipasi kendala-kendala yang dihadapi seperti permasalahanpermasalahan yang timbul dari pekerjaannya supaya dapat dipahami, dimengerti dan dapat diatasi dalam hal pelaksanaan kerjanya

\section{Keberhasilan Usaha}

Keberhasilan usaha UMKM dapat dikatakan berhasil apabila mendapat laba, walaupun laba bukan merupakan satu-satunya aspek yang dinilai dari keberhasilan sebuah usaha. Alasan laba yang menjadi faktor penting karena laba merupakan tujuan dari orang yang melakukan bisnis. Jika terjadi penurunan laba atau ketidakstabilan laba, maka pengusaha atau perusahaan akan kesulitan untuk melakukan atau mengoperasikan kegiatan usahanya dan menjaga ketahanan usahanya.

Suryana (2011:66) menyatakan bahwa "untuk menjadi wirausaha yang sukses seseorang harus memiliki ide atau visi bisnis serta kemauan dan keberanian untuk menghadapi risiko baik waktu maupun uang".

Adapun langkah (dimensi) menuju sukses atau berhasil sebagai wirausaha dalam usahanya sebagai berikut : 1) Adanya visi dan tujuan yang jelas; 2) Ketersediaan untuk mengambil resiko uang dan waktu; 3) Perencanaan yang terorganisir; 4) Kerja keras sesuai dengan tingkat kepentingan; 5) Pengembangan hubungan yang baik dengan karyawan, pelanggan, pemasok, dan lainnya; 6) Tanggungjawab terhadap keberhasilan atau kegagalan.

Dari pendapat dan pemahaman diatas dapat disimpulkan bahwa keberhasilan usaha sebagai wirausaha perorangan atau organisasi adalah yang mempunyai visi, misi, selalu berfikir positif, bekerja keras, berpengalaman, mempunyai inovasi serta motivasi, membangun hubungan dengan karyawan, pelanggan, pemasok, dan lainnya yang ditandai dengan beberapa ciri seperti mendapatkan keuntungan, mendapatkan nilai tambah, bisa mandiri dan berguna bagi orang lain.

\section{METODOLOGI PENELITIAN}

Penelitian ini menggunakan pendekatan kuantitatif dengan pengujian hipotesis menggunakan perhitungan statistik. Perhitungan dilakukan dengan menggunakan software atau aplikasi Statistical Program for Social Science (SPSS) versi 23, kemudian dilakukan penafsiran terhadap data yang diperoleh sehingga diketahui pengaruh pelatihan $\left(\mathrm{X}_{1}\right)$ dan keterampilan $\left(\mathrm{X}_{2}\right)$ baik secara simultan maupun secara parsial terhadap keberhasilan usaha (Y) Mitra Binaan UMKM PT Karya Masyarakat Mandiri Dompet Dhuafa Republika. Keterkaitan dari ketiga variabel yang diteliti dapat digambarkan menjadi model paradigma penelitian berikut ini : 


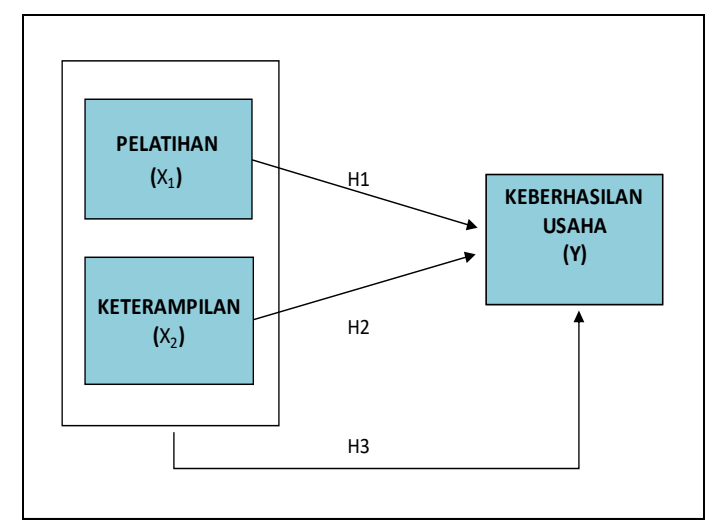

Gambar 1. Model Paradigma Penelitian

Populasi yang menjadi unit analisis dalam penelitian ini adalah seluruh mitra binaan PT Karya Masyarakat Mandiri Dompet Dhuafa Republika yang ada di wilayah Pasar Minggu Jakarta sebanyak 6 kelompok dan berjumlah 50 orang. Teknik sampling yang digunakan adalah sensus karena sampelnya keseluruhan anggota populasi yang ada. Mengingat jumlah populasi hanya sebesar 50 orang, maka diambil keseluruhan untuk dijadikan sampel tanpa mengambil sampel dalam jumlah tertentu. Sehingga sampel dari penelitian ini adalah seluruh anggota mitra binaan PT Karya Masyarakat Mandiri Dompet Dhuafa Republika.

Metode penelitian yang digunakan adalah deskriptif dan verifikatif. Penelitian deskriptif ini untuk mendapatkan informasi yang seluasluasnya terhadap objek penelitian pada suatu masa tertentu. Kemudian mengukur variabel penelitian, dengan cara menghitung dimensi variabel penelitian melalui parameter dan teknik pengukuran statistik serta melakukan perhitungan analisis regresi linier berganda dan koefisien determinasi.

E. HASIL DAN PEMBAHASAN

Analisis Regresi Linier Berganda
Output dari hasil pengolahan data dengan menggunakan SPPS diperoleh hasil sebagai berikut :

Tabel 1 Hasil Perhitungan Uji Regresi Linear Berganda

\begin{tabular}{|c|c|c|c|c|c|}
\hline \multicolumn{6}{|c|}{ Coefficients $^{a}$} \\
\hline \multirow[t]{2}{*}{ Model } & \multicolumn{2}{|c|}{$\begin{array}{l}\text { Unstandardize } \\
\text { d Coefficients }\end{array}$} & \multirow{2}{*}{\begin{tabular}{|l} 
Standardize \\
d \\
Coefficients \\
Beta
\end{tabular}} & \multirow[t]{2}{*}{$\mid t$} & \multirow[t]{2}{*}{ Sig } \\
\hline & $B$ & $\begin{array}{l}\text { Std. } \\
\text { Error }\end{array}$ & & & \\
\hline (Constant) & 18.345 & 6.916 & & $\begin{array}{l}2.65 \\
2\end{array}$ & $\begin{array}{l}.01 \\
1\end{array}$ \\
\hline 1 Pelatihan & .310 & .109 & .356 & $\begin{array}{l}2.85 \\
0\end{array}$ & $\begin{array}{l}.00 \\
6\end{array}$ \\
\hline $\begin{array}{l}\text { Keterampila } \\
\text { n }\end{array}$ & .355 & .117 & .378 & $\begin{array}{l}3.02 \\
6\end{array}$ & $\begin{array}{l}.00 \\
4\end{array}$ \\
\hline
\end{tabular}

a. Dependent Variable: Keberhasilan usaha

Sumber : Hasil penelitian (2018)

Berdasarkan tabel 1 di atas, maka dapat dibentuk persamaan regresi linier berganda pengaruh pelatihan dan keterampilan terhadap keberhasilan usaha sebagai berikut :

$$
\begin{aligned}
Y=18,345 & +0,310 X_{1} \\
& +0,355 X_{2}
\end{aligned}
$$

Persamaan regresi di atas dapat dijelaskan sebagai berikut :

- Konstanta sebesar 18,345 ini berarti jika pelatihan dan keterampilan nilainya adalah 0 , maka keberhasilan usaha nilainya adalah 18,345.

- Koefisien regresi pelatihan $\left(\mathrm{X}_{1}\right)$ sebesar 0,310 artinya jika variabel independen lainnya tetap dan pelatihan mengalami kenaikan $1 \%$, maka keberhasilan usaha akan naik sebesar 0,310. Koefisien bernilai positif artinya terjadi hubungan positif antara pelatihan dengan keberhasilan usaha, yang berarti semakin baik pelatihan satu orang pedagang mitra binaan, maka akan meningkatkan keberhasilan usaha sebesar 0,310. Seiring dengan penerapan pelatihan yang baik, maka keberhasilan usaha mitra binaan akan meningkat.

- Koefisien regresi keterampilan $\left(\mathrm{X}_{2}\right)$ sebesar 0,355 artinya jika variabel 
independen lainnya tetap dan keterampilan mengalami kenaikan $1 \%$ maka nilai keberhasilan usaha akan mengalami peningkatan sebesar 0,355. Koefisien bernilai positif artinya terjadi hubungan positif antara keterampilan dengan keberhasilan usaha, yang berarti semakin baik keterampilan satu orang pedagang mitra binaan, maka akan meningkatkan keberhasilan usaha sebesar 0,355. Seiring dengan keterampilan yang meningkat, maka keberhasilan usaha mitra binaan akan meningkat.

\section{Pengujian Hipotesis Simultan (Uji F)}

Hipotesis statistik untuk uji $\mathrm{F}$ sebagai berikut :

$\mathrm{H}_{0} \quad$ Tidak terdapat pengaruh positif dan signifikan antara pelatihan dan keterampilan secara simultan terhadap keberhasilan usaha mitra binaan PT Karya Masyarakat Mandiri Dompet Dhuafa Republika.

$\mathrm{H}_{1}$ Terdapat pengaruh positif dan signifikan antara pelatihan dan keterampilan secara simultan terhadap keberhasilan usaha mitra binaan PT Karya Masyarakat Mandiri Dompet Dhuafa Republika.

Tabel 2 Hasil Perhitungan Uji Simultan

ANOVA $^{\mathrm{b}}$

\begin{tabular}{|l|l|l|l|l|l|l|}
\hline \multicolumn{2}{|l|}{ Model } & $\begin{array}{l}\text { Sum of } \\
\text { Squares }\end{array}$ & df & $\begin{array}{l}\text { Mean } \\
\text { Square }\end{array}$ & F & Sig. \\
\hline \multirow{2}{*}{1} & Regression & 1039.353 & 2 & 519.677 & 13.675 & $.000^{b}$ \\
& Residual & 1786.050 & 47 & 38.001 & & \\
\cline { 2 - 5 } & Total & 2825.403 & 49 & & & \\
\hline
\end{tabular}

a. Predictors: (Constant), Pelatihan, Keterampilan

b. Dependent Variable: Keberhasilan Usaha

Sumber : Hasil penelitian (2018)

Berdasarkan hasil uji Anova didapatkan nilai $\mathrm{F}$ penelitian sebesar 13,675. Kemudian dibandingkan dengan $\mathrm{F}$ tabel dengan $\alpha=5 \%$, $(\mathrm{k} ; \mathrm{n}-\mathrm{k})=(2 ; 50$ $2)=(2 ; 47)$, diperoleh $F$ tabel $=2,76$. Dari nilai-nilai di atas terlihat bahwa nilai $\mathrm{F}$ hitung > F-tabel $(13,675>2,76)$.
Sehingga $\mathrm{H}_{0}$ ditolak dan $\mathrm{H}_{1}$ diterima, artinya hasil penelitian mununjukan bahwa terbukti terdapat pengaruh positif dan signifikan antara pelatihan dan keterampilan secara simultan terhadap keberhasilan usaha mitra binaan PT Karya Masyarakat Mandiri Dompet Dhuafa Republika.

\section{Pengujian Hipotesis Parsial (Uji t)}

Selanjutnya dilakukan uji hipotesis parsial untuk melihat pengaruh masing-masing variabel bebas terhadap variabel terikat. Hasil uji parsial $(\mathrm{t}$ hitung) dapat dilihat pada tabel 1 diatas.

\section{Pengujian Hipotesis Parsial Pelatihan $\left(\mathbf{X}_{1}\right)$}

$\mathrm{H}_{0} \quad$ Tidak terdapat pengaruh positif

: dan signifikan antara pelatihan terhadap keberhasilan usaha mitra binaan PT Karya Masyarakat Mandiri Dompet Dhuafa Republika.

$\mathrm{H}_{1} \quad$ Terdapat pengaruh positif dan : signifikan antara pelatihan terhadap keberhasilan usaha mitra binaan PT Karya Masyarakat Mandiri Dompet Dhuafa Republika.

Berdasarkan hasil perhitungan sebagaimana tercantum pada tabel 1 untuk pelatihan diperoleh nilai t hitung sebesar 2,850. Dibandingkan dengan tabel distribusi t dengan $\alpha=5 \%,(\alpha / 2 ; n$ $\mathrm{k}-1)=(0,025 ; 47)$, diperoleh $\mathrm{t}$-tabel $=$ 2,021. Dari nilai-nilai di atas terlihat bahwa nilai t-hitung $>\mathrm{t}$-tabel $(2,850>\mathrm{t}$ tabel 2,021), maka $\mathrm{H}_{0}$ ditolak dan $\mathrm{H}_{1}$ diterima, artinya bahwa pelatihan berpengaruh positif dan signifikan terhadap keberhasilan usaha. Pengaruh positif diartikan, bahwa semakin meningkat pelatihan maka akan meningkat pula keberhasilan usaha mitra binaan PT Karya Masyarakat Mandiri Dompet Dhuafa Republika. 


\section{Pengujian Hipotesis Parsial Keterampilan $\left(\mathbf{X}_{2}\right)$}

$\mathrm{H}_{0} \quad$ Tidak terdapat pengaruh positif dan signifikan antara keterampilan terhadap keberhasilan usaha mitra binaan PT Karya Masyarakat Mandiri Dompet Dhuafa Republika.

$\mathrm{H}_{1} \quad$ Terdapat pengaruh positif dan signifikan antara keterampilan terhadap keberhasilan usaha mitra binaan PT Karya Masyarakat Mandiri Dompet Dhuafa Republika.

Berdasarkan hasil perhitungan sebagaimana tercantum pada tabel 1 untuk keterampilan diperoleh nilai $\mathrm{t}$ hitung sebesar 3,026. Dibandingkan dengan tabel distribusi t dengan $\alpha=5 \%$, $(\alpha / 2 ; n-k-1)=(0,025 ; 47)$, diperoleh t-tabel $=2,021$. Dari nilai-nilai di atas terlihat bahwa nilai t-hitung $>\mathrm{t}$-tabel $(3,026>\mathrm{t}$ tabel 2,021), maka $\mathrm{H}_{0}$ ditolak dan $\mathrm{H}_{1}$ diterima, artinya bahwa keterampilan berpengaruh positif dan signifikan terhadap keberhasilan usaha. Pengaruh positif artinya bahwa semakin meningkat keterampilan maka akan meningkat pula keberhasilan usaha mitra binaan PT Karya Masyarakat Mandiri Dompet Dhuafa Republika.

\section{Koefisien Determinasi}

koefisien determinasi dengan menggunakan SPSS diperoleh koefisien determinasi $\left(\mathrm{R}^{2}\right) \quad$ sebesar $\quad 0,368$ sebagaimana tersaji pada tabel berikut ini :

Tabel 3 Koefisien Determinasi

\begin{tabular}{|l|l|l|l|l|}
\hline Model & $\mathrm{R}$ & $\begin{array}{l}\mathrm{R} \\
\text { Square }\end{array}$ & $\begin{array}{l}\text { Adjusted } \\
\text { Square }\end{array}$ & $\begin{array}{l}\text { Std. Error of } \\
\text { the } \\
\text { Estimate }\end{array}$ \\
\hline 1 & $.607^{\mathrm{a}}$ & .368 & .341 & 6.16450 \\
\hline
\end{tabular}

Sumber : Hasil penelitian (2018)

Pada tabel di atas dapat dilihat bahwa nilai koefisien determinasi antara pelatihan dan keterampilan terhadap keberhasilan usaha mitra binaan adalah sebesar 0,368. Hal ini menunjukkan bahwa besarnya pengaruh pelatihan dan keterampilan terhadap keberhasilan usaha mitra binaaan PT Karya Masyarakat Mandiri Dompet Dhuafa Republika sebesar adalah 36,8\% sedangkan $63,2 \%$ dipengaruhi oleh variabel lainnya yang tidak diteliti dalam penelitian ini.

\section{F. KESIMPULAN DAN SARAN}

\section{Kesimpulan}

Berdasarkan hasil penelitian dan pembahasan yang telah dilakukan dapat disimpulkan sebagai berikut :

1. Pada umumnya pelatihan yang telah dilakukan oleh pendamping terhadap mitra binaan sudah tergolong baik, namun masih terdapat tanggapan responden masih menilai rendah terhadap metode pelatihan yang digunakan. Hal ini menunjukan bahwa metode penyampaian pelatihan tidak mudah diterima oleh mitra binaan sehingga metode pelatihan perlu ditinjau kembali dan ditingkatkan.

2. Kemudian pada keterampilan, umumnya tingkat keterampilan mitra binaan sudah tergolong baik namun terkait keterampilan dalam menyelesaikan masalah (prolem solving) yang terjadi masih rendah, mitra binaan belum mampu memecahkan masalah dengan menggunakan akal dan logika.

3. Terbukti secara empiris bahwa pelatihan berpengaruh positif terhadap keberhasilan usaha mitra binaan PT Karya Masyarakat Mandiri Dompet Dhuafa Republika, dimana semakin baik pelaksanaan pelatihan dalam membina mitra binaan, maka akan semakin 
meningkat juga keberhasilan usaha mitra binaan.

4. Terbukti secara empiris bahwa keterampilan (skill) berpengaruh positif terhadap keberhasilan usaha mitra binaan PT Karya Masyarakat Mandiri Dompet Dhuafa Republika, dimana semakin meningkat tingkat keterampilan (skill) mitra binaan, maka akan semakin meningkat juga keberhasilan usaha mitra binaan.

5. Terbukti bahwa pelatihan dan keterampilan secara simultan berpengaruh positif terhadap keberhasilan usaha mitra binaan PT Karya Masyarakat Mandiri Dompet Dhuafa Republika, dimana semakin baik pelaksanaan pelatihan dan meningkatnya tingkat keterampilan mitra binaan, maka akan semakin meningkat juga keberhasilan usaha mitra binaan.

\section{Saran}

Berdasarkan hasil penelitian yang telah diperoleh, pada bagian akhir ini dikemukakan beberapa saran sebagai berikut :

1. Agar metode pelatihan yang digunakan lebih mudah diserap oleh mitra binaan, maka agar ditambahkan pada pelatihan cara peragaan, simulasi, dan menyentuh alatnya langsung tidak hanya menunjukan dalam gambar melalui materi presentasi tapi barangnya dihadirkan pada saat pelatihan. Kemudian tempat pelatihan tidak jauh dengan domisili para mitra binaan berada.

2. Agar diberikan materi keterampilan yang mendalam terkait dengan cara identifikasi dan pemecahannya dengan menggunakan akal dan logikanya dalam menjalankan pekerjaannya. Kemudian dihadirkan narasumber yang telah berhasil melakukan usaha untuk berbagi (sharing) cara mengolah yang lebih menarik yang punya pembeda (differentiation) dengan yang lainnya dan dilakukan secara mendalam termasuk pemecahan masalah dengan menggunakan akal dan logikanya dalam menjalankan pekerjaannya.

3. Oleh karena pelatihan dan keterampilan baik secara parsial maupun simultan berpengaruh positif terhadap keberhasilan usaha mitra binaan, maka diharapkan para pendamping terus membina dan meningkatan cara yang terbaik untuk membantu mitra binaan dari hulu ke hilir dengan cara mengadakan pertemuan rutin dan monitoring setiap triwulan, atau semesteran dan tahunan, sehingga apa yang menjadi kendala dapat teratasi dengan segera.

\section{DAFTAR PUSTAKA}

Chang, Jane and Alison Rieple, (2013), Assessing Students' Enterpreneurial Skill Development in Live Project, Journal of Small Business and Enterprise Development, Vol 20, No 1, pp. 36-49.

Hasibuan, Malayu S. P., Drs., H. (2012), Manajemen Sumber Daya Manusia, Edisi Revisi, Jakarta: PT, Bumi Aksara.

Kaswan, (2013), Pelatihan dan Pengembangan Untuk Meningkatkan Kinerja SDM, Bandung: Alfabeta.

Noe, Raymond A., Hollenbeck, John R.., Gerhart, Barry., Wright, Patrick M., (2011), Manajemen Sumber Daya Manusia Mencapai Keunggulan, Edisi 6, Jakata: Salemba Empat.

Sofyandi, Herman, (2013), Manajemen Sumber Daya Manusia, Cetakan Kedua, Yogyakarta: Graha Ilmu.

Suryana, (2011), Kewirausahaan Pedoman Praktis : Kiat dan Proses Menuju Sukses, Jakarta: Salemba Empat. 